\title{
Grass Species Adaptability in the Southern High Plains-a 36-Year Assessment
}

\author{
H.V. ECK AND P.L. SIMS
}

\section{Abstract}

A 36-yr old species adaptation test was evaluated and the relative quality of some persisting native and introduced grass species was determined. The site was Conlen loam on the Rita Blanca National Grassland in Dallam County, Texas. Of the 25 species planted, only yellow bluestem (Bothriochloa ischaemum), 1 Caucasian bluestem (Bothriochloa caucasica), and galleta (Hilaria jamesii) tended to dominate the plots on which they were originally planted. Yellow and Caucasian bluestem had spread into plots planted to other grasses but galleta had spread very little. Yellow bluestem was as high or higher in protein, mineral content, and digestibility (IVDMD) than the other grasses analyzed [Caucasian bluestem, galleta, sideoats grama (Bouteloua curtipendula), blue grama (Bouteloua gracilis), and western wheatgrass (Agropyron smithii)]. The contents of Caucasian bluestem and galleta were not significantly different from those of yellow bluestem, except that galleta was lower in IVDMD, especially when mature. These 3 grasses merit consideration in range seeding programs on Conlen and similar soils in the Southern High Plains.

For many years, there has been a continuing search for grasses that will increase the productivity of rangelands. Both introduced species and improved selections of native species have been investigated. On the Southern High Plains, there have been some successes with introduced species but when prolonged droughts occur, the introduced species are often replaced by annual weeds, native grasses, or persistant introduced grasses from adjacent or nearby plots. Sites of adaptation studies are often destroyed after the selections are rated and little attention is given to plants that may have invaded the test species. Although comparatively short-term adaptation studies are valuable for cursory evaluation of species, they do not evaluate long-term persistance, indicate aggressiveness of species in invading other species, nor indicate species which may become prevalent where a test species has failed.

\footnotetext{
Authors are soil scientist, USDA-ARS, Conservation and Production Research Laboratory, Bushland, Texas 79012; range scientist, USDA-ARS, Southern Plains Range Research Station, Woodward, Okla. 73801.

This article is a contribution from USDA, Agricultural Research Service, P.O. Drawer 10, Bushland, Texas 79012.

The authors wish to acknowledge Robert G. Childress, District Ranger, Rita Blanca National Grassland, for providing essential background information and for his cooperation during the investigations.

Scientific names follow USDA-SCS (1971) National List of Scientific Plant Names. Manuscript received July 6, 1983.
}

The purpose of this study was to evaluate the standing crop and species composition on a $36-\mathrm{yr}$ old adaptation test site and to determine the relative seasonal quality of some native and introduced species that persisted on the site.

\section{History}

In 1942, the Nursery Division of the Soil Conservation Service was involved in revegetation studies in areas of the Texas Panhandle that had been cropped and abandoned during the "Dust Bowl" era. They conducted a grass adaptability study on Conlen loam (fine, loamy, carbonatic, mesic Calciorthidic Paleustoll) approximately $37 \mathrm{~km}$ north and $13.5 \mathrm{~km}$ west of Dalhart, Dallam County, Texas. The Sunray-Conlen soil association makes up about $25 \%$ of Dallam County. The soils are used for crops and range. The natural vegetation type in the area is shortgrass prairie. Most common species on undisturbed Conlen loam soils are sideats grama (Bouteloua curtipendula) and blue grama (Bouteloua gracilis). Elevation at the site is approximately $1260 \mathrm{~m}$ above sea level. Annual precipitation at Dalhart averages $43 \mathrm{~cm}$. Departures from that average for 1942 through 1979 are shown in Figure 1. Approximately $85 \%$ of the precipitation falls during the warm season,

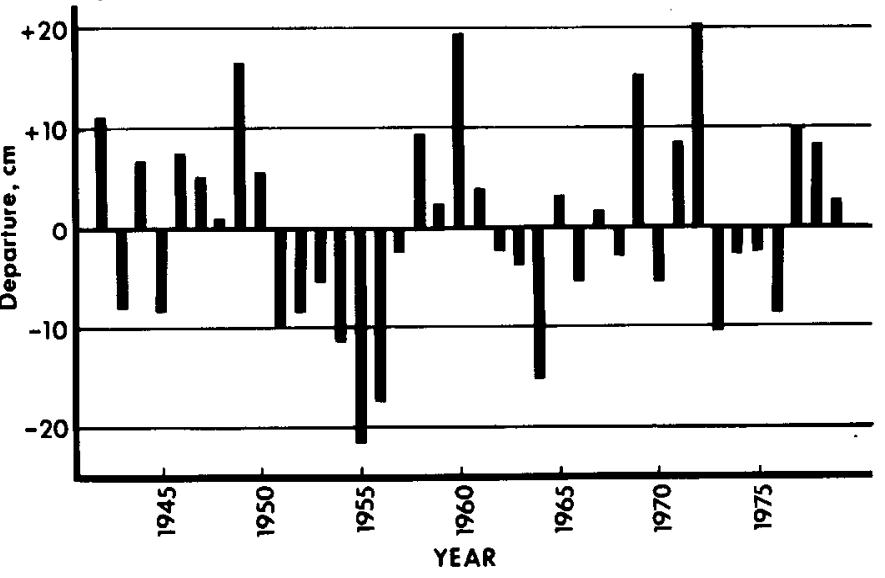

Fig. 1. Departure from average annual precipitation $(43 \mathrm{~cm})$ at Dalhart, Texas. 1942-1979. 
April through October. The average frost-free period is 178 days with the average last occurrence of $0^{\circ} \mathrm{C}$ or below in the spring and the first occurrence in the fall being 23 April and 18 October, respectively, (Ford and Fox 1975).

The grasses were planted in sudangrass (Sorghum vulgare) stubble on 3 May 1942. Twenty-nine plots (approximately $4.3^{8} 61 \mathrm{~m}$ ) were planted to 25 species of grasses. There were duplicate plots of little bluestem (Schizachyrium scoparium), sideoats grama, blue grama, and switchgrass (Panicum virgatum) and single plots of 21 other species. Where 2 plots of the same species were planted, different selections of the species were used. Species planted and identification numbers of seed sources are given in Tables 1, 2, and 3. The "Kg" numbers were those of the Kansas SCS Plant Materials Center. The Kansas numbering system is still in use. The system used in Texas has been changed and we have been unable to locate a key to the CT numbers.

The surrounding area was planted to a mixture of blue grama, sideoats grama, little bluestem, and sand lovegrass (Eragrostis trichodes). The blue grama seed contained some sand dropseed (Sporobolus cryptandrus) the sideoats grama seed contained some blue grama, hairy grama (Bouteloua hirsuta), and sand dropseed.

The soil was very dry at seeding time. The first effective rains after seeding occurred in early July. A rather uniform thin stand was observed on all plots on 29 July 1942. A heavy growth of sudangrass was also present at that time. Further information on stand establishment is sketchy; however, an undated memo indicated that Russian wildrye (Elymus junceus), plains bristlegrass (Setaria macrostachya), and blue panicum (Panicum antidotale) did not become established.

In 1954, the plot area was cross-fenced to exclude grazing on one-half of each plot. Otherwise, after establishment and until this study was initiated, the plots and the surrounding area were grazed for about 6 months annually, beginning in May or June.

\section{Methods and Materials}

In 1978 and 1979, grazing was excluded on the entire area until after major growth had occurred and forage inventories were made (8 August and 6 August, respectively). After the forage inventories, cattle were allowed on the grazed area. Forage inventories, as described by Shoop and McIlvain (1963), were made on plots that had been seeded to yellow bluestem (Bothriochloa ischaemum), Caucasian bluestem, western wheatgrass (Agropyron smithii), two sideoats grama selections, and galleta (Hilaria jamesii).

Step-point analyses for species composition were made on all of the plots on 28 June 1978. This procedure follows closely that described by Brown (1954). Each of 4 individuals identified the species nearest to the boot tip at 25 points along 4 transects through each plot. These 100 points were used to determine the relative plant species composition in each of the 29 plots for both the ungrazed and grazed areas.

Yellow bluestem, Caucasian bluestem (Bothriochloa caucasica), western wheatgrass, sideoats grama, blue grama, and galleta were sampled periodically and analyzed for crude protein (CP), phosphorus $(\mathrm{P})$, potassium $(\mathrm{K})$, calcium $(\mathrm{Ca})$, magnesium $(\mathrm{Mg})$, and in vitro dry matter disappearance (IVDMD). Samples were taken at 18 dates between May 1978 and March 1980 . Corresponding sampling dates in the successive growing and dormant seasons for each year were usually within 12 days of each other, thus years were used as replicates in statistical analyses. Dates in Figure 2 are "average" sampling dates, and values plotted are averages for the two sampling years. Plants were collected from the grazed area except at a few sampling dates during the dormant season when it was necessary to collect plants from the ungrazed area. This was done because sufficient material was not present on the grazed area. Forage samples were collected to simulate grazing. Plant parts sampled were those that were being removed by livestock. Phenological stage at the time of collection was recorded for each species.

Chemical analyses for $\mathbf{N}, \mathbf{P}$, and $\mathrm{K}$ were by the methods of Thomas et al. (1967). Calcium and $\mathrm{Mg}$ were determined by atomic absorption ${ }^{1}$ on the wet digest obtained in the above method. In vitro dry matter disappearance was determined by the method of Tilley and Terry (1963) as modified by Barnes et al. (1971).

Statistical analysis of chemical data was by analysis of variance. When significant " $F$ " values were obtained, Duncan's multiple range test (Duncan 1955) was used to separate means.

'Revision of analytical methods for atomic absorption spectrophotometry. 1968. Perkin-Elmer, Norwalk, CT 06852.

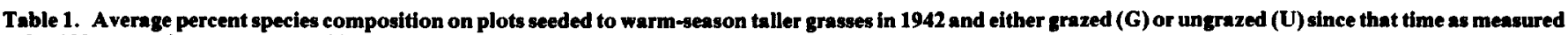
by 100 step points per plot on 28 June 1978.

\begin{tabular}{|c|c|c|c|c|c|c|c|c|c|c|c|c|c|c|c|c|}
\hline \multirow[b]{3}{*}{ Species encountered $^{2}$} & \multicolumn{16}{|c|}{ Planted Grasses (I.D. No.') } \\
\hline & \multicolumn{2}{|c|}{$\begin{array}{l}\text { Bothriochloa } \\
\text { ischaemum } \\
\text { (Kg 495) }\end{array}$} & \multicolumn{2}{|c|}{$\begin{array}{c}\text { Bothriochloa } \\
\text { caucasica } \\
\left(\mathrm{K}_{\mathrm{B}} 40\right)\end{array}$} & \multicolumn{2}{|c|}{$\begin{array}{l}\text { Schizachyrium } \\
\text { scoparium } \\
\text { (CT 1580) }\end{array}$} & \multicolumn{2}{|c|}{$\begin{array}{l}\text { Schizachyrium } \\
\text { scoparium } \\
\text { (CT 1844) }\end{array}$} & \multicolumn{2}{|c|}{$\begin{array}{c}\text { Andropogon } \\
\text { hallit } \\
\text { (CT 1806) }\end{array}$} & \multicolumn{2}{|c|}{$\begin{array}{c}\text { Sorghastrum } \\
\text { mutans } \\
(\mathrm{Kg} \mathrm{494)}\end{array}$} & \multicolumn{2}{|c|}{$\begin{array}{l}\text { Panicum } \\
\text { virgatum } \\
\text { (CT 1810) }\end{array}$} & \multicolumn{2}{|c|}{$\begin{array}{l}\text { Panicum } \\
\text { virgatum } \\
\text { (CT 208) }\end{array}$} \\
\hline & $\mathbf{U}$ & 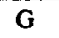 & $\mathbf{U}$ & $G$ & $\mathbf{U}$ & $\mathbf{G}$ & $\mathbf{U}$ & $G$ & $\mathbf{U}$ & $\mathbf{G}$ & $\mathbf{U}$ & $\mathbf{G}$ & $\mathbf{U}$ & $\mathbf{G}$ & $\mathbf{U}$ & $G$ \\
\hline $\begin{array}{l}\text { Bothriochloa caucasica } \\
\text { Andropogon hallii } \\
\text { Agropyron smithii }\end{array}$ & 2 & - & 80 & 72 & 90 & 61 & $\begin{array}{r}74 \\
5 \\
-\end{array}$ & $\frac{36}{1}$ & $\begin{array}{r}52 \\
19 \\
2\end{array}$ & $\begin{array}{r}12 \\
2 \\
-\end{array}$ & 12 & - & 15 & 2 & 7 & 6 \\
\hline $\begin{array}{l}\text { Bouteloua curtipendula } \\
\text { Bouteloua gracilis } \\
\text { Bothriochloa ischaemum }\end{array}$ & - & $\begin{array}{r}1 \\
18 \\
72\end{array}$ & $\begin{array}{r}-1 \\
19\end{array}$ & $\begin{array}{r}2 \\
5 \\
18\end{array}$ & $\begin{array}{l}1 \\
9\end{array}$ & $\begin{array}{r}1 \\
18\end{array}$ & $\begin{array}{r}2 \\
16 \\
1\end{array}$ & $\begin{array}{r}5 \\
23 \\
24\end{array}$ & $\begin{array}{r}10 \\
14 \\
1\end{array}$ & $\begin{array}{l}11 \\
27 \\
32\end{array}$ & $\begin{array}{r}60 \\
6 \\
\end{array}$ & $\begin{array}{r}52 \\
31 \\
4\end{array}$ & $\begin{array}{r}58 \\
4 \\
2\end{array}$ & $\begin{array}{l}15 \\
30 \\
50\end{array}$ & $\begin{array}{r}58 \\
5 \\
1\end{array}$ & $\begin{array}{l}56 \\
15 \\
20\end{array}$ \\
\hline $\begin{array}{l}\text { Hilaria jamesii } \\
\text { Sporobolus cryptandrus } \\
\text { Aristida purpurescens }\end{array}$ & & & & & & & - & 1 & $\underline{5}$ & $\begin{array}{l}5 \\
4\end{array}$ & $\begin{array}{l}2 \\
1 \\
-\end{array}$ & $\overline{7}$ & 2 & - & 2 & - \\
\hline $\begin{array}{l}\text { Sorghastrum nutans } \\
\text { Panicum virgatum } \\
\text { Salsola kali }\end{array}$ & - & 6 & & & & & & & & & & & $\begin{array}{r}14 \\
1\end{array}$ & - & 20 & - \\
\hline Other plants & 4 & 3 & - & 3 & & & 2 & 1 & 2 & 2 & 3 & 5 & 4 & 3 & 6 & 3 \\
\hline
\end{tabular}

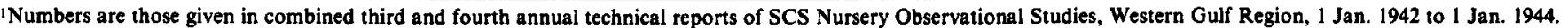

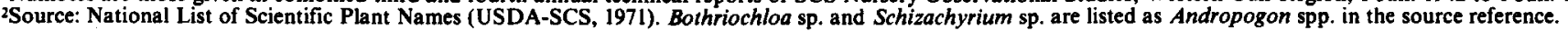




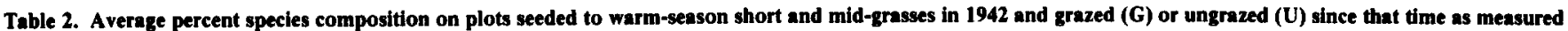
by 100 step points per plot on 28 June 1978 .

\begin{tabular}{|c|c|c|c|c|c|c|c|c|c|c|c|c|c|c|c|c|c|c|c|c|c|}
\hline \multirow[b]{3}{*}{ Species encountered ${ }^{2}$} & \multicolumn{21}{|c|}{ Planted grasses (I.D. No. ${ }^{1}$ ) } \\
\hline & \multicolumn{2}{|c|}{$\begin{array}{c}\text { Buchloe } \\
\text { dactyloides } \\
\text { (CT 1815) }\end{array}$} & \multicolumn{2}{|c|}{$\begin{array}{l}\text { Bouteloua } \\
\text { curtipendula } \\
\text { (CT 482) }\end{array}$} & \multicolumn{2}{|c|}{$\begin{array}{l}\text { Bouteloua } \\
\text { curtipendula } \\
\text { (C| 1794) }\end{array}$} & \multicolumn{2}{|c|}{$\begin{array}{l}\text { Bouteloua } \\
\text { gracilis } \\
\text { (CT 1246) }\end{array}$} & \multicolumn{2}{|c|}{$\begin{array}{l}\text { Bouteloua } \\
\text { gracilis } \\
\text { (CT 408) }\end{array}$} & \multicolumn{3}{|c|}{$\begin{array}{c}\text { Hilaria } \\
\text { jamesii } \\
(\mathrm{CT} 1790)\end{array}$} & \multicolumn{2}{|c|}{$\begin{array}{c}\text { Setaria } \\
\text { macros- } \\
\text { tachya } \\
\text { (CT 1258) }\end{array}$} & \multicolumn{2}{|c|}{$\begin{array}{l}\text { Eragrostis } \\
\text { curvula } \\
\text { (CT 1796) }\end{array}$} & \multicolumn{2}{|c|}{$\begin{array}{l}\text { Eragrostis } \\
\text { trichodes }\end{array}$} & \multicolumn{2}{|c|}{$\begin{array}{l}\text { Panicum } \\
\text { antidotale } \\
\text { (CT 1843) }\end{array}$} \\
\hline & $\mathrm{U}$ & G & U & G & $\overleftarrow{U}$ & G & $\mathrm{D}$ & G & $\mathrm{U}$ & $\mathbf{G}$ & i & U & $\mathbf{G}^{-}$ & U & $\mathbf{G}$ & $\mathrm{U}$ & $\mathrm{G}^{-}$ & $\mathbf{u}$ & $\mathbf{G}$ & $\mathrm{U}$ & G \\
\hline \multirow{2}{*}{$\begin{array}{l}\text { Bothriochloa caucasica } \\
\text { Agropyron smithii } \\
\text { Bouteloua curtipendula }\end{array}$} & $\overline{1}$ & 1 & 3 & 5 & 3 & 2 & $\begin{array}{l}7 \\
3\end{array}$ & 3 & 1 & 2 & & 4 & 1 & 4 & - & 25 & 3 & 26 & 4 & 16 & 6 \\
\hline & 10 & 5 & 43 & 20 & 57 & 58 & 47 & 57 & 9 & 40 & 2 & 3 & 16 & 67 & 62 & 52 & 22 & 28 & 12 & 23 & 18 \\
\hline \multirow{2}{*}{$\begin{array}{l}\text { Bouteloua gracilis } \\
\text { Bothriochloa ischaemum } \\
\text { Hilaria jamesii }\end{array}$} & 3 & 15 & 7 & 17 & 17 & 24 & 15 & 14 & 5 & 14 & & 1 & 2 & 6 & 20 & 1 & 18 & 13 & 8 & 10 & 7 \\
\hline & - & 9 & - & 7 & 2 & - & - & 1 & - & 2 & & 50 & $\begin{array}{r}3 \\
75\end{array}$ & $\overline{3}$ & $\begin{array}{l}3 \\
1\end{array}$ & 1 & 34 & - & 57 & - & 62 \\
\hline \multirow{2}{*}{$\begin{array}{l}\text { Sporobolus cryptandrus } \\
\text { Aristida purpurescens } \\
\text { Aristida longiseta }\end{array}$} & 6 & 1 & - & 2 & 1 & 1 & 5 & 1 & 3 & 6 & & 1 & - & 1 & - & - & 2 & - & 1 & - & 1 \\
\hline & 31 & $\begin{array}{l}15 \\
10\end{array}$ & $\begin{array}{l}7 \\
5\end{array}$ & 15 & - & 9 & $\begin{array}{l}4 \\
5\end{array}$ & 16 & $\begin{array}{l}7 \\
4\end{array}$ & 24 & & & & $\begin{array}{l}3 \\
3\end{array}$ & 5 & - & 13 & - & $\begin{array}{r}10 \\
1\end{array}$ & & \\
\hline \multirow{2}{*}{$\begin{array}{l}\text { Aristida purpurea } \\
\text { Buchloe dactyloides } \\
\text { Sorghastrum nutans }\end{array}$} & - & 10 & 5 & 7 & & & 8 & - & 5 & 3 & & & & 5 & 4 & & & & & & \\
\hline & & & & & & & & & & & & & & & & 6 & - & 20 & - & 34 & - \\
\hline \multirow{2}{*}{$\begin{array}{l}\text { Andropogon } \\
\text { saccharoides } \\
\text { Salsola kali }\end{array}$} & & & & & & & & & & & & & & & & 6 & - & & & 7 & - \\
\hline & 42 & 15 & 28 & 15 & 14 & 6 & 13 & - & 50 & 4 & & & & - & l & & & & & & \\
\hline Other Plants & 7 & 3 & 4 & 5 & 6 & - & 3 & 8 & 4 & 3 & & 1 & 2 & 8 & 4 & 9 & 8 & 12 & 7 & 10 & 6 \\
\hline
\end{tabular}

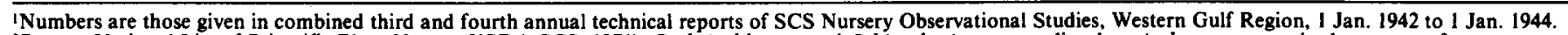

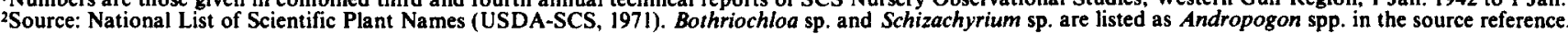

\section{Results and Discussion}

Precipitation at Coldwater, Texas, about $11 \mathrm{~km}$ northeast of the study, totaled $28 \mathrm{~cm}$ ( $15 \mathrm{~cm}$ below average) in 1978 and $46 \mathrm{~cm}(3 \mathrm{~cm}$ above average) in 1979. Warm-season precipitation (April through October) totaled $20 \mathrm{~cm}$ in 1978 and $38 \mathrm{~cm}$ in 1979 . In 1978, $71 \%$ of the warm-season precipitation occurred in April through June. July through October precipitation totaled only $6 \mathrm{~cm}$, thus the vegetation was dormant or near dormant for much of that period. Note that precipitation at Dalhart was considerably higher than at Coldwater in 1978 (Fig. 1). In 1979, precipitation was more plentiful and more evenly distributed and growth continued through late summer.

\section{Species Composition}

Yellow and Caucasian bluestem dominated the plots on both the ungrazed and grazed areas (Table 1). Yellow bluestem had a species composition of 94 and $72 \%$ while Caucasian bluestem had 80 and $72 \%$ composition in their respective ungrazed and grazed plots. Sand bluestem (Andropogon hallii) comprised 19 and $2 \%$ of the species in its ungrazed and grazed plots, respectively. Little bluestem, Indiangrass (Sorghastrum nutans), and switchgrass were rarely found. Sideoats grama and galleta sustained reasonably good stands 36 years after planting (Table 2). Generally, these 2 species comprised more than $50 \%$ of the vegetation composition. Blue grama, a principal native to the area, made up only 5 to $15 \%$ of the vegetation. Buffalograss (Buchloe dactyloides) comprised $16 \%$ of the vegetation on the grazed area of the plot while it did not occur on the ungrazed area. Plains bristlegrass, weeping lovegrass (Eragrostis curvula), sand lovegrass, and blue panicum either were not present or were minor components of the vegetation.

Western wheatgrass made up 25 and $1 \%$ of the vegetation on the ungrazed and grazed areas, respectively (Table 3 ). None of the other cool-season grasses [Crested wheatgrass (Agropyron cristatum), Canada wildrye (Elymus canadensis), Russian wildrye, green needlegrass (Stipa viridula), Indian ricegrass (Oryzopsis hymenoides), and needleandthread (Stipa comata)] persisted. Prairie dropseed (Sporobolus asper), alkali sacaton (Sporobolus airoides), giant sandreed (Calamovilfa gigantea), and sand dropseed did not maintain consequential stands.

The ability of plants to spread or invade other sites is an indica- tion of their adaptability. Some species were as abundant on adjacent plots as they were on plots where they were planted. Caucasian bluestem was quite prevalent in the neighboring plots. For example, it made up 82 and $52 \%$ of the species composition on the ungrazed portions of the little bluestem and sand bluestem plots, respectively. Although Caucasian bluestem was found in almost every plot, it was more abundant in the ungrazed than the grazed areas. In contrast, yellow bluestem had a higher percent species composition in the grazed compared to the ungrazed plots. Sims and Dewald (1982) reported that these Old World bluestems react ecologically as secondary successional species and increase under grazing and disturbances in their natural habitat (Harlan et al. 1958).

Sideoats grama was a significant invader in some plots. The percent species composition across all plots was higher for sideoats grama than any other species. Average species composition of sideoats grama in the ungrazed plots was $34 \%$ compared to $26 \%$ in the grazed plots. Composition of blue grama across all ungrazed plots was $9 \%$ compared to about $20 \%$ in the grazed plots. It occurred in almost every plot.

Sideoats grama was found on 27 ungrazed and 29 grazed plots while Caucasian bluestem was found on 27 ungrazed and 25 grazed plots. Yellow bluestem, on the other hand, occurred in only 12 ungrazed plots and 27 grazed plots. Although sand dropseed was relatively widespread and occurred on 19 ungrazed and 17 grazed plots, species composition was only 3 and $2 \%$, respectively. Russian thistle (Salsola kali), a transient species, occurred on about one-third of the ungrazed plots and one-fourth of the grazed plots. Scattered silver bluestem (Andropogon saccharoides) plants were present on 5 plots on which planted grasses were not found.

A review of the grass species adaptabilty trials on similar sites in the Southern Plains shows results similar to those obtained in our study. McGinnies et al. (1983) concluded from studies in southeast Colorado that blue grama, sideoats grama, and yellow bluestem were among the most persistent warm-season grasses planted. Vallentine (1971) summarized recommendations for adaptable species for planting in the Southern Plains and listed many of the plants that were evaluated in the Dalhart plantings. Although many grass species have been shown to be persistent and useful in the Southern Plains, planting success is still marginal for some of the species (Great Plains Council 1966, Merkel and Herbel 1973). 


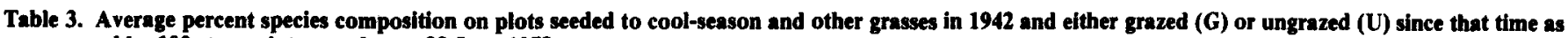
measured by 100 step points per plot on 28 June 1978.

\begin{tabular}{|c|c|c|c|c|c|c|c|c|c|c|c|c|c|c|c|c|c|c|c|c|c|c|}
\hline \multirow[b]{3}{*}{ Species encountered ${ }^{2}$} & \multicolumn{22}{|c|}{ Planted grasses (I.E. No. ${ }^{1}$ ) } \\
\hline & \multicolumn{2}{|c|}{$\begin{array}{l}\text { Agro- } \\
\text { pyron } \\
\text { cristatum } \\
\text { (CT 1799) }\end{array}$} & \multicolumn{2}{|c|}{$\begin{array}{c}\text { Agro- } \\
\text { pyron } \\
\text { smithii } \\
\text { (CT 1816) }\end{array}$} & \multicolumn{2}{|c|}{$\begin{array}{c}\text { Elymus } \\
\text { canadensis } \\
\text { (CT 1802) }\end{array}$} & \multicolumn{2}{|c|}{$\begin{array}{c}\text { Elymus } \\
\text { junceus } \\
\text { (CT 1813) }\end{array}$} & \multicolumn{2}{|c|}{$\begin{array}{l}\text { Calamo- } \\
\text { vilfa } \\
\text { gigantea }\end{array}$} & \multicolumn{2}{|c|}{$\begin{array}{c}\text { Oryzopsis } \\
\text { hymen- } \\
\text { noides } \\
\text { (CT 1819) }\end{array}$} & \multicolumn{2}{|c|}{$\begin{array}{c}\text { Stipa } \\
\text { viridula } \\
\text { (CT 1766) }\end{array}$} & \multicolumn{2}{|c|}{$\begin{array}{c}\text { Stipa } \\
\text { comata } \\
\text { (CT 1523) }\end{array}$} & \multicolumn{2}{|c|}{$\begin{array}{c}\text { Sporo- } \\
\text { bolus } \\
\text { asper } \\
\text { (Kg 1695) }\end{array}$} & \multicolumn{2}{|c|}{$\begin{array}{c}\text { Sporo- } \\
\text { bolus } \\
\text { airoides } \\
\text { (CT 1820) }\end{array}$} & \multicolumn{2}{|c|}{$\begin{array}{c}\text { Sporo- } \\
\text { bolus } \\
\text { cryptandrus } \\
\text { (CT 1804) }\end{array}$} \\
\hline & $\mathrm{U}$ & G & $U$ & $\mathrm{G}$ & $\mathrm{U}$ & $\mathbf{G}$ & $\mathrm{U}$ & $\mathbf{G}$ & $\mathbf{U}$ & $\mathrm{G}$ & $\mathrm{U}$ & G & $\mathrm{U}$ & $\mathbf{G}$ & $\mathrm{U}$ & $\mathbf{G}$ & $\mathrm{U}$ & $\mathbf{G}^{\prime}$ & $\mathbf{U}$ & $\mathrm{G}^{\prime}$ & $\mathrm{U}$ & G \\
\hline $\begin{array}{l}\text { Bothriochloa caucasica } \\
\text { Andropogon hallii }\end{array}$ & 41 & 17 & 8 & 10 & 14 & 4 & - & 1 & 26 & 2 & 19 & 1 & 3 & 14 & 25 & 13 & $\begin{array}{l}6 \\
2\end{array}$ & 1 & $\begin{array}{l}3 \\
4\end{array}$ & - & 2 & 3 \\
\hline Agropyron smithii & 29 & - & 25 & 1 & 22 & 9 & 9 & 17 & & & & & & & & & & & & & - & 1 \\
\hline Bouteloua curtipendula & 8 & 9 & 14 & 3 & 23 & 7 & 27 & 26 & 22 & 52 & 51 & 33 & 61 & 50 & 53 & 5 & 37 & 21 & 36 & 56 & 48 & 36 \\
\hline Bouteloua gracilis & 10 & 25 & 2 & 18 & 5 & 42 & 7 & 23 & 14 & 12 & 8 & 20 & 13 & 17 & 5 & 48 & 13 & 20 & 20 & 26 & 15 & 26 \\
\hline Bothriochloa ischaemum & 1 & 28 & - & 18 & - & 8 & - & 4 & 1 & 8 & 1 & 4 & 一 & 1 & - & 1 & 4 & 23 & - & 2 & - & 1 \\
\hline Hilaria jamesii & & & & & 1 & - & & & 14 & 6 & 9 & 36 & & & & & - & 1 & 2 & 12 & 1 & 2 \\
\hline Sporobolus cryptandrus & 2 & 1 & 4 & 3 & 2 & 2 & 7 & 1 & 2 & 4 & & & 2 & - & & & 2 & 4 & 5 & - & 1 & 3 \\
\hline Aristida purpurescens & - & 13 & 22 & 11 & 23 & 8 & 15 & 7 & 2 & 5 & & & 2 & 11 & - & 7 & - & 6 & & & 1 & 7 \\
\hline Aristida longiseta & & & - & 8 & & & - & 9 & 3 & 1 & 一 & 4 & 4 & - & & & & & & & 4 & 2 \\
\hline Aristida purpurea & & & - & 11 & - & 9 & 6 & 4 & 6 & 7 & 2 & - & 11 & 3 & 1 & - & & & & & 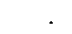 & \\
\hline Sorghastrum nutans & & & & & & & & & & & & & & & & & 6 & 9 & 17 & 一 & & \\
\hline Andropogon saccharoides & & & & & & & & & & & & & & & 5 & - & 7 & 8 & - & 6 & & \\
\hline Salsola kali & 4 & - & 22 & 15 & 7 & 5 & 25 & 3 & 2 & - & - & 2 & 1 & - & & & & & 5 & - & 1 & 7 \\
\hline Other plants & 5 & 7 & 3 & 2 & 3 & 6 & 4 & 4 & 8 & 4 & & & 3 & 4 & 11 & 4 & 9 & 7 & 8 & 4 & 13 & 12 \\
\hline
\end{tabular}

1Numbers are those given in combined third and fourth annual technial reports of SCS Nursery Observational Studies, Western Gulf Region, 1 Jan. 11942 to 1 Jan. 1944. 2Source: National List of Scientific Plant Names (USDA-SCS, 1971). Bothriochloa sp. and Schizachyrium sp. are listed as Andropogon spp. in the source reference.

\section{Standing Crop of Established Grasses}

Yellow bluestem, Caucasian bluestem, western wheatgrass, sideoats grama, and galleta had sufficient cover of the planted species to be recognized as established stands. Yellow and Caucasian bluestems had the greatest standing crop in the ungrazed plots and galleta had the greatest standing crop in the grazed area. Yellow bluestem had $2,037 \mathrm{~kg} / \mathrm{ha}$ compared to $1,845 \mathrm{~kg} /$ ha for Caucasian bluestem and 324, 662, and $802 \mathrm{~kg} /$ ha for western wheatgrass, sideoats grama, and galleta plots, respectively (Table 4).

The ungrazed yellow and Caucasian bluestem plots were nearly closed communities. After almost 40 years since planting, Caucasian bluestem was the second most dominant species in the yellow bluestem plot and yellow bluestem was the second most dominant species that had become established in the ungrazed Caucasian bluestem plot. While the Old World bluestems were not particularly abundant in the western wheatgrass and sideoats grama plots in the ungrazed condition, they did represent a considerable portion of the standing crop in the ungrazed galleta plot (Table 4). In the ungrazed western wheatgrass, sideoats grama, and galleta plots, the standing crop of other grasses was relatively high, particularly buffalograss and threeawns (Aristida sp.). Blue grama did not invade the ungrazed yellow and Caucasian bluestem plots, but was found in the ungrazed western wheatgrass, sideoats grama, and galleta plots.

The average production of the established species on the ungrazed area was $1,055 \mathrm{~kg} /$ ha compared to $437 \mathrm{~kg} / \mathrm{ha}$ on the grazed area. Galleta was the only planted species of the 5 established stands that produced more in the grazed $(1,135 \mathrm{~kg} / \mathrm{ha})$ than the ungrazed $(802 \mathrm{~kg} / \mathrm{ha}$ ) plot. Production of blue grama across all plots was $18 \mathrm{~kg} / \mathrm{ha}$ for the ungrazed plots compared to $72 \mathrm{~kg} / \mathrm{ha}$ for the grazed plots.

The average production of grasses in the ungrazed area was $1,415 \mathrm{~kg} / \mathrm{ha}$ compared to $840 \mathrm{~kg} / \mathrm{ha}$ in the grazed plots. The differences between the grazed and ungrazed plots in standing crops of sand dropseed, the 2 Old World bluestems, and "other plants" were not great enough to show a distinct grazing response.

\section{Chemical Composition of Forage, and Digestibility}

Percentages of CP, $P, K, C a$, and $\mathrm{Mg}$ and IVDMD of simulated forage samples of the 5 "established" grasses and blue grama 9 sampling dates between May and March are shown in Figure 2.

\section{Crude Protein}

Crude protein levels in the grasses at the different sampling dates are shown in Figure 2A. Western wheatgrass was as high or higher in CP than the other grasses at all sampling dates. Yellow bluestem, although ranked fifth at the first sampling, compared favorably with western wheatgrass at the other dates and ranked second over the nine sampling dates. Blue grama averaged lower, but not significantly lower, than western wheatgrass and yellow bluestem. The other 3 grasses averaged significantly lower than western wheatgrass but not significantly different from yellow bluestem. If only the frost-free season is considered (20 May - 24 Oct) the ranking of the grasses is not changed.

\section{Phosphorus}

In May, sideoats grama and western wheatgrass were highest, blue grama and galleta were intermediate, and the 2 bluestems were lowest in P (Fig. 2B). In June, yellow bluestem was highest, Caucasian bluestem was lowest, and the other $\mathbf{4}$ grasses were intermediate and similar in P levels. At later dates during the growing season, Caucasian bluestem was consistently as low or lower in $P$ than the other grasses. Although $P$ levels in all grasses decreased as the season progressed, those in yellow bluestem and galleta did not diminish as early as those in the other grasses. After frost, all grasses were low in $\mathbf{P}$ concentration. Galleta averaged highest in $\mathbf{P}$ $(0.17 \%)$ and Caucasian bluestem averaged lowest $(0.12 \%)$. The other 4 grasses were intermediate and not significantly different from galleta or Caucasian bluestem.

\section{Potassium}

The grasses were variable in $\mathrm{K}$ concentration (Fig. 2C). In May, levels varied from 1.0 (blue grama) to $2.1 \%$ (western wheatgrass). Potassium concentration in the other 4 grasses ranged between 1.0 and $1.5 \%$. In May, June, and July, yellow bluestem and western wheatgrass maintained $\mathrm{K}$ levels near $1.5 \%$ or higher while concentrations in the other grasses ranged from about 0.7 to $1.3 \%$. 

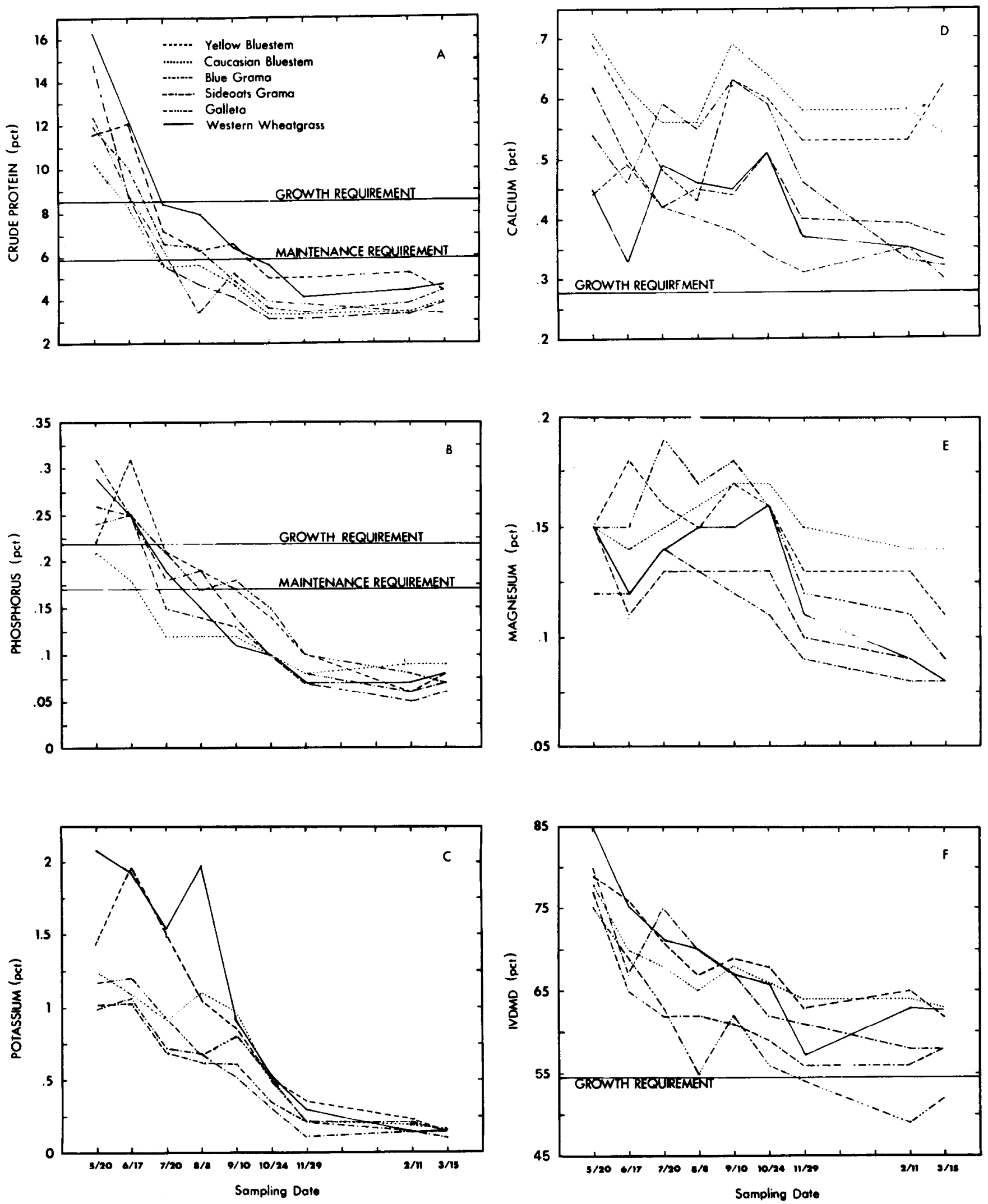

Fig. 2. Average percent composition of crude protein (A), phosphorus (B), potassium (C), calcium (D), magnesium (E), and in vitro dry matter digestibility (F) for six grasses collected on 9 dates in each of 1978 and 1979 from plantings near Dalhart, Texas. 
Table 4. Standing crop of herbage (kg/ha) by species and species group in 1978 and 1979 on plots planted to five species on the Rita Blanca National Grasalands in 1942 and either grazed or ungrazed since that time (see text). Grazed areas were ungrazed during sampling years.

\begin{tabular}{|c|c|c|c|c|c|c|c|c|c|c|c|c|}
\hline & \multicolumn{12}{|c|}{ Species Planted } \\
\hline & \multicolumn{2}{|c|}{$\begin{array}{l}\text { Bothriochloa } \\
\text { ischaemum }\end{array}$} & \multicolumn{2}{|c|}{$\begin{array}{c}\text { Bothriochloa } \\
\text { caucasica }\end{array}$} & \multicolumn{2}{|c|}{$\begin{array}{c}\text { Agropyron } \\
\text { smithii }\end{array}$} & \multicolumn{2}{|c|}{$\begin{array}{c}\text { Bouteloua } \\
\text { curtipendula }\end{array}$} & \multicolumn{2}{|c|}{$\begin{array}{c}\text { Bouteloua } \\
\text { curtipendula }\end{array}$} & \\
\hline & 1978 & 1979 & 1978 & 1979 & 1978 & 1979 & 1978 & 1979 & 1978 & 1979 & 1978 & 1979 \\
\hline & \multicolumn{12}{|c|}{ Ungrazed } \\
\hline Bothriochloa ischaemum & 988 & 3087 & 253 & 17 & 8 & 18 & 4 & - & 6 & 6 & 212 & 748 \\
\hline Bothriochloa caucasica & 258 & - & 1119 & 2565 & 25 & 1 & 52 & 150 & 2 & 12 & 25 & 28 \\
\hline Agropyron smithii & - & - & - & 2 & 187 & 460 & - & - & - & 13 & - & - \\
\hline Bouteloua curtipendula & 1 & 10 & 4 & - & 152 & 54 & 480 & 752 & 710 & 704 & 34 & 55 \\
\hline Hilaria jamesii & - & 3 & - & - & - & - & - & - & - & - & 1099 & 504 \\
\hline Bouteloua gracilis & - & - & 1 & - & 48 & 52 & 10 & 11 & 57 & 12 & 19 & 4 \\
\hline Andropogon hallii & - & - & - & - & - & - & - & - & - & - & - & - \\
\hline Sporobolus cryptandrus & 31 & 17 & 8 & - & 52 & 99 & 18 & 22 & 16 & - & 13 & 2 \\
\hline Other grasses & 4 & - & 1 & - & 349 & 145 & 238 & 399 & 8 & 254 & 4 & 260 \\
\hline $\begin{array}{l}\text { Total grasses } \\
\text { Other plants }\end{array}$ & $\begin{array}{r}1282 \\
26\end{array}$ & $\begin{array}{r}3117 \\
64\end{array}$ & 1386 & $\begin{array}{r}2584 \\
10\end{array}$ & $\begin{array}{l}821 \\
445\end{array}$ & $\begin{array}{l}840 \\
298\end{array}$ & $\begin{array}{l}802 \\
406\end{array}$ & $\begin{array}{r}1334 \\
274\end{array}$ & $\begin{array}{l}799 \\
198\end{array}$ & $\begin{array}{r}1001 \\
370\end{array}$ & $\begin{array}{r}1406 \\
4\end{array}$ & $\begin{array}{r}1601 \\
18\end{array}$ \\
\hline \multirow[t]{2}{*}{ Total standing crop } & 1308 & 3181 & 1387 & 2594 & 1266 & 1138 & 1208 & 1608 & 997 & 1371 & 1410 & 1620 \\
\hline & \multicolumn{12}{|c|}{ Grazed } \\
\hline Bothriochloa ischaemum & 211 & 604 & 66 & 3 & 66 & 333 & 47 & 384 & 1 & 74 & 55 & 155 \\
\hline Bothriochloa caucasica & - & - & 302 & 798 & 22 & 22 & 38 & 309 & 10 & 47 & 27 & 133 \\
\hline Agropyron smithii & - & - & - & - & 12 & 49 & - & - & - & - & - & 2 \\
\hline Bouteloua curtipendula & 18 & 48 & 24 & 63 & 65 & 45 & 159 & 179 & 368 & 287 & 36 & 84 \\
\hline Hilaria jamesii & - & - & - & 1 & - & - & - & - & - & 7 & 1365 & 905 \\
\hline Bouteloua gracilis & 106 & 201 & 11 & 7 & 123 & 149 & 31 & 26 & 112 & 86 & 18 & - \\
\hline Andropogon hallii & - & - & - & - & 92 & - & - & l & - & 1 & - & - \\
\hline Sporobolus cryptandrus & 37 & 87 & 2 & 3 & 27 & 113 & 47 & 81 & 6 & 6 & 2 & - \\
\hline Other grasses & 2 & 31 & 7 & - & 161 & 119 & 258 & 257 & 50 & 263 & 6 & 131 \\
\hline $\begin{array}{l}\text { Total grasses } \\
\text { Other plants }\end{array}$ & $\begin{array}{r}374 \\
76\end{array}$ & $\begin{array}{l}971 \\
322\end{array}$ & $\begin{array}{r}412 \\
12\end{array}$ & $\begin{array}{l}875 \\
167\end{array}$ & $\begin{array}{l}568 \\
102\end{array}$ & $\begin{array}{l}830 \\
154\end{array}$ & $\begin{array}{l}580 \\
137\end{array}$ & $\begin{array}{r}1237 \\
166\end{array}$ & $\begin{array}{l}547 \\
170\end{array}$ & $\begin{array}{l}770 \\
166\end{array}$ & $\begin{array}{r}1509 \\
16\end{array}$ & $\begin{array}{r}1410 \\
58\end{array}$ \\
\hline Total standing crop & 450 & 1304 & 424 & 1042 & 670 & 984 & 717 & 1403 & 717 & 936 & 1525 & 1468 \\
\hline
\end{tabular}

Between 20 July and 8 August, $K$ levels in yellow bluestem and western wheatgrass decreased about one-third while decreases in the other grasses were less. By frost, all 6 grasses were low in $\mathrm{K}$, and concentrations continued to decrease as weathering continued after frost. Western wheatgrass and yellow bluestem averaged 1.0 and $0.9 \%$, respectively, while blue grama and sideoats grama both averaged $0.5 \%$. Caucasian bluestem and galleta were intermediate with 0.7 and $0.6 \% \mathrm{~K}$, respectively.

\section{Calcium}

Calcium concentrations of grasses did not decline as much as $\mathrm{CP}, \mathrm{P}$, and $\mathrm{K}$ concentrations declined as the plants matured (Fig. 2D). The 2 bluestems were highest in $\mathrm{Ca}$ at the beginning of the season and remained high during all sampling dates. Blue grama and western wheatgrass were lowest in Ca. Galleta and sideoats grama were intermediate in $\mathrm{Ca}$ concentration. Calcium concentrations decreased after frost.

\section{Magnesium}

Magnesium concentrations, like $\mathrm{Ca}$ did not decline significantly during the growing season (Fig. 2E). The $\mathbf{2}$ grama grasses were as low or lower in $\mathrm{Mg}$ than the other grasses at most dates and averaged lowest. The 2 bluestems and galleta were highest and western wheatgrass was intermediate in $\mathrm{Mg}$ concentration. Magnesium concentrations did not decrease significantly after frost.

\section{IVDMD}

In May, IVDMD of the grasses ranged from 75 (galleta) to $85 \%$ (western wheatgrass) and averaged $79 \%$ (Fig. 2F). Digestibility decreased as the season progressed. The average decreased to $63 \%$ prior to frost and decreased to $59 \%$ at the first sampling after frost. Western wheatgrass and the 2 Old World bluestems were highest, the 2 grama grasses were intermediate, and galleta was lowest in IVDMD.

\section{Nutritional Value}

Recommended nutrient requirements for range animals for ges- tation and maintenance and for lactation and growth have been suggested by Cook and Harris (1968) and Church (1972). These requirements are lower than feedlot standards (NRC 1976) but represent required levels for range animals assuming that the daily dry matter intake requirements are being met. These are shown in Figure 3 for $\mathrm{CP}$ and $\mathrm{P}$. Church (1972) gives $0.16 \%$ as the maintenance requirement and $0.28 \%$ as the growth requirement of $\mathrm{Ca}$. Crude protein, $\mathrm{P}$, and $\mathrm{Ca}$ are the nutrients most likely to be limiting in rangeland production systems (Church 1972).

Cook and Harris (1968) indicate that the metabolizable energy (ME) requirement for gestation and maintenance is about 1.46 $\mathrm{kcal} / \mathrm{g}$ and for lactation and growth reaches $1.98 \mathrm{kcal} / \mathrm{g}$ of forage. Minson (1979) summarized several papers that relate nutrient components in forages to their ME levels. The relationship $y=0.20$ +0.33 IVDMD is an estimate of the metabolizable energy of grass hays. This relationship was used to determine the level of IVDMD required to meet the energy requirements as shown in Figure $2 \mathrm{~F}$. An IVDMD of $38 \%$ will meet the ME requirement for gestation or maintenance. An IVDMD of $54 \%$ would supply about $1.98 \mathrm{kcal}$ of $\mathrm{ME} / \mathrm{g}$ of forage as required for lactation and growth.

The CP level required by dry pregnant cows is $5.9 \%$ and that required for maintenance of $200 \mathrm{~kg}$ steers or heifer calves is $8.5 \%$. Thus, calves grazing these grasses would require some protein supplement by mid- or late July in order to continue weight gains. Dry pregnant cows grazing Caucasian bluestem, sideoats grama, or galleta would require protein supplement by early to midAugust for maintenance needs. By late October, CP concentration in all grasses had dropped to levels at which supplementation would be required for all classes of beef cattle.

The $P$ level required by dry pregnant cows and maintenance of $200 \mathrm{~kg}$ steers or heifer calves is about $0.17 \%$. Dietary $P$ levels must be $0.22 \%$ or greater for $200 \mathrm{~kg}$ steers or heifer calves to gain 0.5 $\mathrm{kg} /$ day. All grasses contained sufficient $P$ to meet these standards in mid-June, but by mid-July cattle grazing pure stands of Caucasian bluestem or sideoats grama would require supplemental P. By early August, all grasses except yellow bluestem and blue grama 
would require supplementation, and by mid-September non of the grasses contained sufficient $\mathbf{P}$ to meet the above-stated requirements.

The minimum $\mathbf{K}$ requirement for growing finishing steers and pregnant cows is 0.6 to $0.8 \%$ (NRC 1976). The grasses maintained sufficient $K$ until September, but after that, supplement would be required for all large cattle.

The minimum $\mathrm{Ca}$ requirement for dry pregnant cows and that required for maintenance of $200 \mathrm{~kg}$ steers and heifer cows ranges from 0.16 to $0.18 \%$ (Church 1972, NRC 1976). Church (1972) recommends 0.27 to $0.29 \% \mathrm{Ca}$ for lactating cows. Calcium levels in these grases are adequate for beef cattle throughout the year.

The minimum $\mathrm{Mg}$ requirement for beef cattle is given as 0.04 to $0.10 \%$ (NRC 1976). The grasses in this study had $\mathrm{Mg}$ concentrations above the minimum requirement for cattle.

Most of the grasses have sufficient energy to meet the requirement for growth and lactation of range cattle. During winter some additional energy would be required for maximum growth and milk production. Generally, range cows are not expected to produce at these high levels when the range vegetation is dormant.

In New Mexico, Pieper et al. (1978) found the average CP of whole "intact plants" of grazed blue grama, sideoats grama, and galleta to be $6.2 \%$. This compares with $6.3 \%$ in the present study. Savage and Heller (1947) reported similar results. Average protein content of perennial grasses in their study (species included those in the present study) was about $18 \%$ in April, 12\% in May and declined to $6 \%$ or less for the late summer and winter.

The seasonal patterns of $\mathrm{P}, \mathrm{K}$, and $\mathrm{Mg}$ reported by Pieper et al. (1978) and Savage and Heller (1947) were similar to those in this study. Peak levels of these constituents tended to occur a little earlier at this site than at the higher altitude site in New Mexico. However, the average contents were somewhat higher in samples collected at this site where they were collected to simulate grazed forage. The average $\mathrm{Ca}$ content for the grasses was $0.36 \%$ for the New Mexico study compared to $0.48 \%$ for grasses collected from the Texas High Plains.

The IVDMD of the grasses collected in the present study was somewhat higher than that of those collected in New Mexico. Pieper et al. (1978) reported $49 \%$ for blue grama, galleta, and sideoats grama compared to $62 \%$ in the present study. Highest IVDMD in the New Mexico study occurred in July (56\%) and lowest during midwinter (40\%). This compares to a high of $78 \%$ and a low of $56 \%$ from July to midwinter in the Texas High Plains.

\section{Summary and Conclusions}

After 36 years, yellow and Caucasian bluestem dominated both ungrazed and grazed areas of plots on which they were planted and had spread into plots planted to other grasses. Only sideoats grama, a native of the area, was found on as many plots as was Caucasian bluestem. Galleta dominated the plot on which it was planted but had spread very little. Except for galleta on the grazed area, the $\mathbf{2}$ Old World bluestems had highest forage yields of the established grasses under both ungrazed and grazed conditions. Yellow bluestem was as high or higher in CP, mineral content, and IVDMD than the other grasses analyzed. The contents of Caucasian bluestem and galleta were not significantly different from those of yellow bluestem, except that galleta was lower in IVDMD, especially when it was mature. These three grasses merit consideration in range seeding programs on Conlen and similar soils in the Southern High Plains.

\section{Literature Cited}

Barnes, R.T., L.D. Miller, L.F. Bauman, and V.F. Colenbrander. 1971. In vitro dry matter disappearance of brown midrib mutants of maize (Zea mays L.). J. Anim. Sci. 33:881-884.

Brown, D. 1954. Methods of surveying and measuring vegetation. Commonwealth Agricultural Bureau, Bulletin No. 42. Farmham Royal, England.

Church, D.C. 1972. Feeding and nutrition of the beef herd. Part I: Winter Feeding Ch. 8. In: D.C. Church, ed. Digestive physiology and nutrition of ruminants. Vol. 3, Practical Nutrition. Oregon State University Bookstore.

Cook, C.W., and L.E. Harris. 1968. Nutritive value of seasonal ranges. Utah Agr. Exp. Sta. Bull. No, 472.

Duncan, D.B. 1955. Multiple range and multiple $T$ tests. Biometrics 11:1-42.

Ford, Alan R., and Richard W. Fox. 1975. Soil Survey of Dallam County, Texas. USDA-SCS \& FS in cooperation with TAES.

Great Plains Council. 1966. A stand establishment survey of grass plantings in the Great Plains. Univ. of Nebraska, Agr. Exp. Sta., Lincoln.

Harlan, J.R., R.P. Celarier, W.L. Richardson, M.H. Brooks, and K.L. Meka. 1958. Studies on Old World bluestems. II. Oklahoma Agr. Exp. Sta. Tech. Bull. T-72.

McGinnies, W.J., W.G. Hassell, and C.H. Wasser. 1983. A summary of range seeding trials in Colorado. Colorado State Univ. Coop. Ext. Serv., Special Series 21

Merkel, D.L., and C.H. Herbel. 1973. Seeding non-irrigated lands in New Mexico. New Mexico Interagency Range Committee Rep. No. 10.

Minson, D.J. 1979. Relationship of conventional and preferred fractions to determined energy values. p. 72-78. In: W.J. Pigden, C.C. Balch, and M. Graham. Standardization of analytical methodology for feeds. 1979. Proc. of a workshop held in Ottawa, Canada. IDRC.

National Research Council. 1976. Nutrient requirements of domestic animals: Nutrient requirements of beef cattle. (5th revised edition) Nat. Acad. Sci.-Nat. Res. Counc. Washington, D.C.

Pieper, R.D., A.B. Nelson, G.S. Smith, E.E. Parker, E.J.A. Boggins, and C.F. Hatch. 1978. Chemical composition and digestibility of important range grass species in South-central New Mexico. New Mexico Agr. Exp. Sta. Bull. No. 662.

Savage, D.A., and V.G. Heller. 1947. Nutritional qualitities of range forage plants in relation to grazing with beef cattle on the Southern Plains Experimental Range. USDA Tech. Bull. No. 943.

Shoop, M.C., and E.H. Mcllvain. 1963. The micro-unit forage inventory method. J. Range Manage. 16:172-179.

Sims, P.L., and C.L. Dewald. 1982. Old World bluestems and their forage potential for the Southern Plains-A review of early studies. USDAARS ARM-S-28.

Thomas, R.L., R.W. Sheard, and J.R. Moyer. 1967. Comparison of conventional and automated procedures for nitrogen, phosphorus, and potassium analysis of plant material using a single digestion. Agron. J. 59:240-243.

Tilley, J.M.A., and R.A. Terry. 1963. A two-stage technique for the in vitro digestion of forage crops. J. Br. Grassl. Soc. 18:104-111.

USDA-SCS. 1971. National list of scientific plant names. USDA-SCS, Lincoln, Neb.

Vallentine, J.F. 1971. Range development and improvements. Brigham Young Univ. Press, Provo, Utah. 